\title{
World Literature: A Panacea for the Colonial Prejudice of English Literature
}

\author{
Amirhossein Nemati ${ }^{1}$, Ali Hassanpour Darbandi ${ }^{2}$ \\ University of Tehran, IRAN \\ e-mail: ahnemati@ut.ac.ir ${ }^{1}$, ali.hassanpour.d@ut.ac.ir ${ }^{2}$
}

\begin{abstract}
The present study is an attempt to discuss the importance of world literature for English literary studies in the former colonies of England. In this regard, this paper shall refer to the stances adopted by various thinkers against the colonial and ideological essence of English literature in these developing countries. In this part, references are made to postcolonial thinkers and the way they have exposed the barbaric nature of colonialism, in that it has, for decades, marginalized the culture and literature of other nations through cultural (neo)colonialism. Later on, we offer a brief introduction to the history of the emergence of world literature and how it contributes to bridging the gap between nations across continents and ideological divides. The final section is devoted to a recapitulatory remark vis-à-vis the reorientation of the public's eyes towards world literature as a panacea for the colonial prejudice of English literature.
\end{abstract}

Keywords: English literature, world literature, postcolonial studies, multiculturalism, difference.

\section{INTRODUCTION}

In developing a literary canon, some pretty crucial points must be taken into careful consideration such as diversity, appropriateness, and up-to-datedness of the selected materials, structural fertility of the disciplines, correspondence and congruity between the materials presented and the needs and demands of the society, and attention to the latest theoretical and conceptual frameworks to expand and push back the frontiers of knowledge in the present world. Paying scrupulous attention to this issue grows in significance, particularly when it comes to dealing with humanities and social sciences, in that humanities and social sciences are most principally concerned with the essence and complexities of the abstruse and indecipherable nature of human beings. It can, therefore, be argued that no society will develop unless their humanities and social sciences start to develop cultivated perspectives concerning professional education (Anushiravani, 2015, p. 26). From among the various disciplines in the humanities, literature is possessed of a unique position in that it has inextricable spiritual and intellectual ties with different layers and strata of the society. National language and literature are inseparably intertwined with every society's cultural identity and heritage and are thus the carrier of the thoughts, values, and discourses that inhere within the fabric of the society (ibid). Irrefutably, positive and constructive engagement with literary studies can serve as one of the most expeditious ways for researchers who have scholarly obsessions to probe into the cultural and social values of other nations across ideological divides.

This article aims to demonstrate the exclusive position of English literature in propagating the Eurocentric view of literature through acts of cultural imperialism and colonialism in the $19^{\text {th }}$ and early $20^{\text {th }}$ century and study the teething troubles that English literature has with his former colonies in a postcolonial world. The postcolonial world is a world of diversity, plurality, and inclusion of the marginalized, from which the former colonies inherited the English language and combined it with their own flavor. The present study's main objective is to introduce world literature as a panacea for paving the path for a well-balanced English canon that remains inclusive of and open to its former colonies' voices by trying to challenge and overcome the canon's deeply-rooted cultural and ethnopolitical prejudices. As it is argued in this study, world literature can transform the "other" and "different" of the colonial literature to, using a Hegelian terminology, "identity within difference" in the postcolonial literature. In other words, world literature can preserve the valued tradition of English literature, yet it should push back the ideological and circumscriptive frontiers of the canon to incorporate peripheralized literatures, 
particularly those that suffered from the exploitation of their local literature in the colonial era. This study makes every effort to introduce the notion of world literature, bereft of its elitist origin, and conducive to establishing a more democratic and wide-ranging English canon.

The theoretical framework of the study is not predicated upon a single theory, yet it is built upon the arguments derived mostly from the theories of the leftist critics of the English empire such as Terry Eagleton, Homi K. Bhabha, and Alan Sinfield to initially pinpoint and investigate the problems of the English canon. The remedial solution of the world literature for colonial prejudice is comprised of a dialectic of identity and difference, rooted in Hegelian inclusive "Geist" expounded upon in his groundbreaking work Phenomenology of the Spirit. Although a myriad of research papers and theses written on/about world literature around the world have discussed the connection between world literature and Postcolonialism methodically, only a few, if any, have brought together different critical insights of the world literature to suggest a way for the English canon to revise itself. In this regard, the present study tries to blaze a trail in what other counterparts have not fully accomplished.

As the sovereignty of Englishness and English language was increasingly challenged due to migration of the people of the colonized countries back to England, English literature set out to have so many different voices that obliged the Caribbean poet Derek Walcott to assert that "The English language is nobody's special property." Many non-white African and Caribbean educators tried to write poems that would follow the conventional metric lines of English poetry ... (Greenblatt, 2006, p. 2720) and turned the language of former colonies into a language of their own. This paper hopes to benefit from and build upon some postcolonial writers' assertion that English has become a local language in different parts of the world and the notion of English literature has undergone a sea-change with the presence of Indian, Caribbean and African writers and poets ever since. Therefore, English literature, formerly a voice for colonialism, can contribute to world literature not only to make amends but also to build a more comprehensive literary canon.

The article begins with articulating the colonial manipulation of English literature and its prejudices. In the first part, the article touches upon several theories, such as Said's notion of "other" and Sinfield's cultural materialism. Then, the second part introduces world literature and the ways in which it can contribute to the democratization of the postcolonial situation in English literature. The article concludes with a note on some vehement opposition to the all-inclusiveness of world literature.

\section{DISCUSSION}

\section{English Literature and Colonialism}

Many renowned theorists and thinkers have already, particularly in the second half of the twentieth century, been seriously engaged in and lent their voices to the critical discussions about the colonial nature of English literature as an academic discipline all around the world - in countries such as Nigeria, India, Kenya, etc. in particular. This neo-Marxist thinker asserts that the expansion of English literature in the late nineteenth century in England and subsequently in all around the world was achieved and realized chiefly to preserve this nation's values and ideologies of a globallyperpetuated imperial ascendency $(2008$, p. 20). He also asserts that:

In eighteenth-century England, the concept of literature was not confined as it sometimes is today to 'creative' or 'imaginative' writing. It meant the whole body of valued writing in society: philosophy, history, essays, and letters, as well as poems. What made a text 'literary' was not whether it was fictional - the eighteenth century was in grave doubt about whether the new upstart form of the novel was literature at all and many people vulgarized novel as a lowly enterprise that did not value publication-but whether it conformed to certain standards of 'polite letters.' The criteria of what counted as literature, in other words, were frankly ideological: writing which embodied the values and 'tastes' of a particular social class qualified as literature, whereas a street ballad, a popular romance and perhaps even the drama did not. At this historical point, then, the 'value-ladenness' of the concept of literature was reasonably selfevident (ibid, p. 15).

After the ideological clout of religion and church in England declined in the nineteenth-century, the ascendant class of the Victorian society of that time decided to think of an equally powerful alternative, which was literature. In essence, this aim was fulfilled as a result of appropriating literature as a potent and determinative political weapon to serve ill-conceived ideological and political ends. This process, which was imbued with resonances of vicious neo-colonial and the cultural onslaught, was first effectuated in England and then reached out to the outer boundaries of the empire and gradually into all of its vast colonies (ibid, p. 24-25). The far-reaching implication of this event 
was to provoke and intensify indomitable spirits of patriotism inside England and inculcate feelings of grudging respect towards English codes and values inside colonies (Javidshad, 2018, p. 169).

A handsome proportion of the inculcation of such ideological sentiments was mainly attained through the ways in which writers were chosen for public readers in those writers canonized or anthologized were for the most part from among the male English authors from the upper-middle class and protestant sect of the society, the profound implication of which was strongly indicative of the total domination of these groups and cliques over the British society (Javidshad, 2018, p. 169). The preponderance of English writers in the British literary canon was in line with the cultural, political and economic ascendency of England in Great Britain (ibid), a thorny issue which the famed American author and professor of political science at Arizona State University, Michael Hechter designates as "Internal Colonialism" within the British amalgam. This approach ultimately resulted in viewing the internal differences by way of hierarchy and exclusion rather than pluralism and inclusion (Crocco, 2014, p. 24). The instance of this exploitive monopolization can be vividly observed even outside of Britain's borders. The fact that the educational legislatures and policymakers in India had made it obligatory for scholastic and collegiate courses to incorporate works of Shakespeare into their curricula as an embodiment and potent symbol of hierarchy. The voice of primordial truths was well suggestive of Britain's pervasive exertion of ideological leverage into its colonies: "In colonial education policy, the strategy of 'killing' with English classics - especially Shakespeare - proved effective. The study of English literature, with Shakespeare at its center, was promulgated so successfully in India than in the mother country. Moreover, in a double irony, far fewer students are reading Sanskrit than ever before" (Trivedi, 2017, p. 264).

Therefore, the widespread canonization of writers such as William Shakespeare, John Milton, Mathew Arnold, etc. is, besides their literary-aesthetic value, tellingly suggestive of the uppermost ideological significance and position they have occupied in the Eurocentric, sometimes racist literary canon of Great Britain (Javidshad, 2018, p. 140). Viewed in this light, canon and canonical status are nothing more than subjectively conceived human constructs that are principally shaped and informed by the ideology and prejudices of a community of interpreters who bestow upon specific works the non-intrinsic value they enjoy. All we can do then is just describe what happened in history because the canon has no metaphysical or intrinsic qualities that need to be accounted for (Kruger, 2012, p. 32) - "canon is not something that describes the quality of a book, but is something that is done to books" (ibid). The permanent and dominant reign of the aforesaid canon, which incorporates such white English, male figures accordingly resulted in marginalization and suppression of their female counterparts and also other writers who belonged to different and unrecognized religious, racial, and ethnic minorities. According to cultural materialists, centralization and canonization of some certain figures and accordingly suppressive marginalization of others signifies nothing but the ideological relationship between mechanisms of power and works of literature, which is present everywhere a text comes into circulation and promotion. The matter of literary marginalization pales into insignificance when it comes to even recognizing non-white identities. In the eyes of many Victorians, all groups and members who fall into the category of "the other" should be ostracized entirely from all sociopolitical spheres and fall into brisk disregard. Edward W. Said, the well-known literary critic, sheds more light on the matter by stating that: "the entire history of nineteenth-century European thought is filled with such discriminations as these, made between what is fitting for us and what is fitting for them, the former designated as inside, in place, common, belonging, in a word, above, the latter, who are designated as outside, excluded, aberrant, inferior, in a word, below" (Said, 1983, p. 13). As an example, in The Colonies of England (1849), J. A. Roebuck, Benthamite radical and parliamentary ally of John Stuart Mills demonstrated the following guidelines:

I say, that for the mass, the sum of human enjoyment to be derived from this globe which God has given us, it is requisite for us to pass over the original tribes that we find existing in the separate lands which we colonize. When the European comes in contact with any man the other type disappears. Let us not shade our eyes and pretend not to see the results. Hypocrisy is by such a proceeding added to all the evils which we must encounter. The result is the same. (p. 138)

The presence of the "other" must immutably, unwaveringly, and unquestionably be taken as illegitimate and deposed as the pivoting fulcrum of the holistic English identity. There are many instances of the absolute subversion of non-European identity and Oriental literature in Victorian literature and politics. To bring a poignantly vivid example, T. B. Macaulay, the Tory member of the parliament and a proud Victorian once proclaimed:

I have no knowledge of either Sanskrit or Arabic. But I have done what I could to form a correct 
estimate of their value. I have read translations of the most celebrated Arabic and Sanskrit works. I have conversed, both here and at home, with men distinguished by their proficiency in the Eastern tongues. I am quite ready to take the oriental learning at the valuation of the orientalists themselves. I have never found one among them who could deny that a single shelf of a good European library was worth the whole native literature of India and Arabia. The intrinsic superiority of the Western literature is indeed fully admitted by those members of the committee who support the oriental plan of education. (1965, p. 112)

Such records that present an image of the contemptuously condescending attitude of the Westerners towards Oriental literature in the $19^{\text {th }}$ and sometimes $20^{\text {th }}$ century are copious in number and rampant in circulation running a whole gamut of the dialogues of writers, members of parliament, etc. The picture reductively drawn from this supercilious viewpoint is one of the palpable examples of the alleged claim of superiority of the western canon. It is more and more evident that the nineteenth-century attitude was quietly carried and perpetuated until the beginning of the decline of England's imperial ascendency and the process of decolonization in so many different countries, particularly in India. Therefore, one is unavoidably committed to the idea that only after both the minds and lands were decolonized did Oriental literature begin to win the recognition that it deserved and demanded as meritorious literature, a recognition that it was, based on the western standards, heretofore bereft of. Needless to say, there were some few exceptions in this regard, such as Rubáiyát of Omar Khayyám, translated by Edward Fitzgerald.

According to the English literary, political and cultural theorist, Alan Sinfield, reaching a cumulative consensus regarding the choice of the works of the literary canon congruent with the political ends of the reigning system is one of how certain literary figures are turned into the nation's cultural tokens that are appropriated to serve the ideological ends concocted by the empire (Sinfield, 1992, p. 21). This leads to the employment of conservative criticism as the bedrock of the politically influenced climate of academia. This mode of criticism aims at rendering literature "politically agreeable" by making the canon exclusive to certain "suitable" texts, manipulating their interpretations so that some awkward aspects are jettisoned and naturalizing the dissemination of political implications as alleged formal properties (ibid). Consequently, the canon forcefully resists inclusivity and perpetuates its exclusivity and illiberality, depriving its texture and discourse of any decolonial and progressive thinking.
In addition to cultural materialists, postcolonial thinkers, and activists, in a concerted effort, likewise attempted to air grievances against the exclusive and dominant presence of certain literary figures, the canonization of whom was woefully charged with colonial and Eurocentric sentiments. These thinkers forcefully advocate for the entrance and incorporation of literary figures from developing countries into the pervasive literary-social-political spheres to give voice to the silenced and suppressed voices of the people who are pushed back to the margins in both the academic and non-academic communities all around the world. The award-winning, world-renowned Kenyan writer and academic, Ngũgĩ wa Thiong'o was one of the most outspoken critics who reacted against the colonial ascendency of the English language and literature in the world's academia. In an influential and highly contentious memo titled "On the Abolition of the English Department" coauthored with a number of his colleagues in the University of Nairobi, Thiong'o quite vociferously calls for the studies of native African languages and literature to supplant those of English literature within departments of language and English studies (Greenblatt, 2006, p. 2535). According to Thiong'o's polemical arguments, it is necessary that this discipline be less dependent upon and inclined towards "Britain" and attend to other literature in English, such as American, Caribbean, African, and third world and European literature with a comparative perspective and approach (Ashcroft and Griffiths, 1995, p. 439). "The primary duty of any literature department is to illuminate the spirit animating a people, to show how it meets new challenges, and to investigate possible areas of development and involvement" (ibid). This seminal memo garnered worldwide scholarly attention and gradually grew in significance so much that it is now hailed and considered by many as one of the pioneering manifestos of the postcolonial criticism in that it inspired many postcolonial scholars of English to reconsider the practices of this discipline before Edward Said popularized attention to the geopolitics of the disciplines in Orientalism (1978) (Brydon, 2015, p. 3). This ultimately resulted in the democratization of English literary studies in almost all around the world; Thiong'o and his colleagues succeeded in prioritizing the native literature studies in the department of foreign languages and literature of the University of Nairobia department then dominated by an expatriate white professoriate (Amoko, 2010, p. 4). Thiong'o's original memo and his unflagging support for the gradual reformation and abolition of the ideologically-oriented English departments pioneered various further reactionary movements to counter the neocolonial monopolizations attributable to English literary studies. 
This ideologically-informed colonial monopolization perpetrated and perpetuated in the realm of English literary studies will be given appropriate depth and resonance if also viewed from a psychological perspective. In order for the British empire, representing the crux of "Europe" and the "West," to appear as the hub of civilizational plenitude and abundance, the colonized world had to be divested and robbed of any meaningful significance. This strange, mystical representation of unknown orient could not be ontologically obliterated, so the Europeans had to find a way to project their own negative mentality and immorality, lustfulness, and cannibalism on them and exonerate their own guilt (Said, 1978, p. 95). Therefore, as the Indian political psychologist and social theorist, Ashis Nandy writes: "This colonialism colonizes minds in addition to bodies, and it releases forces within colonized societies to alter their cultural priorities once and for all. In the process, it helps to generalize the concept of the modern West from a geographical and temporal entity to a psychological category. The West is now everywhere, within the West and outside, in structures and minds" (Nandy 1983, p. xi qt. in Gandhi, 1998, p. 15-16). "Colonialism, therefore, to put it simply, marks the historical process whereby the 'West' attempts systematically to cancel or negate the cultural difference and value of the "non-West"' (Gandhi, 1998, p. 16).

\section{WORLD LITERATURE}

The concept of world literature (weltliteratur) was initially formulated by the German writer and statesman Johann Wolfgang von Goethe, who maintained that: "poetry is the universal possession of mankind, revealing itself everywhere and at all times in hundreds and hundreds of men... National literature is now a rather unmeaning term; the epoch of world literature is at hand, and everyone must strive to hasten its approach" (Damrosch, 2003, p. 1). World literature is a work that gains in translation: It "is not an infinite, ungraspable canon of works but rather a mode of circulation and of reading, a mode that applies to individual works as to bodies of material, available for reading established classics and new discoveries alike." (ibid, p. 5) The "world literary system" is "one" but "profoundly unequal" (Moretti, 2000, p. 54) that consists of a center (Western Europe and North America), a periphery (Asia and Africa), and a semiperiphery (Latin America, Eastern Europe).

Goethe, with this, was seeking to familiarize and reconcile different cultures and nations employing the powerful medium of literature. Only by virtue of literature, he believed, could human beings transcend the geographical, political, and linguistic demarcations and boundaries; literature ultimately will exert its full transformative power upon the collective spirit of nations all around the world, bringing together their aspirations to build a utopian commonwealth and nationhood. Goethe is considered to be one of the first men of letters to have touched upon and placed under critical, analytical scrutiny the literary chefs-d'oeuvre ${ }^{\mathrm{ii}}$ of other nations, such as eastern literature; he claims: "... the Chinese were writing novels at a time when the Germans were still living in their forests" (Jost, 1974, p. 16). He argues that one should shy away from committing oneself to the confinements that a narrow circle of a single linguistic domain or any isolated part of the universe imposes (ibid). It is also interesting to note that Goethe, at the time, was reading a Chinese novel as his voracious readings were being extended to the Asian literature, including Arabic, Persian, Sanskrit, etc. which were becoming available through prolific translations, particularly by the renowned philologist Sir William Jones, whom Goethe called the "Incomparable Jones" (Robertson, 2016, p. 60) Not surprisingly, lack of national unity in nineteenthcentury Germany chiefly inspired Goethe to take a more transnational stance in his thoughts and writings.

In addition to his overt optimism and highly selective approach, Goethe later became restricted and narrowed in his ideas, conceptual framework, and geographical frame of reference in that his mentality and works incorporated the authentic literary works of only the large European countries such as England, France, Germany, and Italy, and some few literary masterpieces of the east, designated by some as "General Literature." In fact, world literature nowadays is a seedbed of contention and unending dispute with Goethe's cosmopolitan literature on the one hand and Marx and Engel's political economy on the other; since the established goodwill to register the world literary wealth toward reading, teaching, and research is irretrievably inhibited by economic and cultural implications of globalized capital on the networks of textual exchange (Vafa, 2016, p. 6). As César Domínguez et al. (2015) note:

Goethe, in his gesture of recognizing and welcoming the foreign (Chinese) novelist as a fellow contributor to world literature, forgot the translator, the publisher, and the many other agencies that smoothed the road from Beijing to Weimar: economic, philosophical, political, technical agencies. Marx/Engels, in their assertion that a new world had been born from the world-spanning, homogenizing activities of capitalism, took the objects of exchange to be mere incidentals in the story of how the networks of exchange were built. (p. 58) 
More recently, the concept of world literature has been scrupulously reexamined by scholarly figures such as the American literary historian David Damrosch. He contends that world literature is "an "elliptical refraction' of national literature, which, as they circulate among other cultures, retain only some marks of their national origin and gain other qualities in the receiving cultures" (Cuddon, 2013, p. 778). The problem of wanting to become familiar with two or more cultures can be addressed by a collaborative partnership of minds and fruitful association, even among graduate students (ibid).

The Bengali polymath, poet, musician, and artist from the Indian subcontinent, Rabindranath Tagore viewed world literature as consisting of literature which perfectly embodies human values; in this way, it would be possible to diffuse and perpetuate the true, transcendent human spirit among all human species worldwide (Anushiravani, 2015, p. 38). When Tagore was asked to give a speech on comparative literature to the Indian National Council of Education in February 1907 in Calcutta, he decided to give the title of "Vishwa Sahitya," or "World Literature" to his lecture. On the website ${ }^{\mathrm{iii}}$ associated with Comparative Literature Association of India, the following goals are presented for the formulation and development of world literature: "To promote the ideal of one world by appreciation of Comparative Literature beyond national frontiers, and in pursuance thereof to rise above separate identities of single national literatures so that the all-embracing concept of Viswa-Sahitya as visualized by Tagore or Goethe's Weltliteratur may be realized as a measure of international understanding" (qt. in D'haen and Damrosch, 2011, p. 41).

World literature can be viewed as an emancipatory apparatus to elude the snares of imperial and racial discrimination that have, with astonishing celerity, spread over and blighted the history of English literature; it can serve as a mutual lever of recognition both for the colonized and colonizer's society. The colonized could take cognizance of the complications and prohibitions begotten by English literature, thereby identifying and associating the present prejudices of western origins to the claims of racial and cultural superiority. On the other hand, the former colonizer can develop consciousness about the problematics of race and therefore mediate a settlement in its relationship with the colonized nations who are tyrannically cast adrift. Besides this, there is a mutual understanding of one another's genuine and realistic literary status. In the act of reading, there is a balance of identification with the difference that could make both oriental and western readers identify with each other's situation and yet to capitalize on one's different and predetermined backgrounds.
Identity is one of the most fundamental concepts in the history of thought, the crux of the existence and definition of which would not have been conceivable had the concept of "the other" not existed. Georg Wilhelm Friedrich Hegel, the renowned German philosopher, embarks upon the task of fully exploring the concept of identity by tendering some authoritative accounts and reasonings. This Hegelian concept is one of the most controversial issues in Postcolonial studies. Like previous philosophers such as Kant and Descartes, he develops his definition of what identity is composed of. He concludes that the first knowledge we attain is immediate, and thus the attempt to describe its identity is also immediate (Hegel, 1998, p. 90). According to him, identity is a matter of self-relation; it is identified as a unified whole when reflected upon itself and not about other entities. On the other hand, the difference is an external reflection on identities and spotting out their otherness (Hegel, 1998, p. 229). Therefore, the dialectical relation of identity and difference is highly contingent upon one another; that is, these two notions are mutually-constitutive. Hegel believed a balance between identity and difference is the key to a better philosophical and political understanding. The case of human identity also falls into the same philosophical discourse of definition and valuation, based on the reasonings that all human beings, notwithstanding their apparent differences such as the differences of color, race, nationality, etc. are essentially the same in nature in that they are inherently possessed of certain shared essential features such as their biological origins, biological history, etc. This approach steers clear of both sides of racial, ethnic, and national dogmatism and rejects the identification of all people under the same banner. Nevertheless, at the same time, it avoids excessive and overrated emphasis on differences such as those that can be found in the eclecticism of postmodern discourse. This concept of identity is also cautious of getting caught in a potential trap of essentialization of identities and rejects a relativism of differences and indifference in tensions at the same time.

How can the concept of world literature be conducive to the restoration and preservation of identities? It can equip people with a panoramic lens to gain a clearer and more deconstructive view and awareness of other marginalized groups' conditions, at the same time as noticing that there are many similar concerns for many people around the world to sympathize with and sometimes act in support of them. World literature maintains a set of literary masterpieces that, like Goethe, could accomplish the goals of universal humanity (Eckermann, 2011, p. 132). In contrast, the concept of world literature had no independent significance for Marx and Engels at the time of the 
publication of the Communist Manifesto. Their search for a new world literature was to publish in many languages at the same time and in different places; the text was ipso facto supposed to bring into being a new type of writing. The German literary critic and philosopher, Martin Puchner maintains that:

Written from the point of view of the international, countryless proletariat, the Manifesto hopes to create its addressee through its own international, literary practice. In much the same way, the Manifesto is the pinnacle of bourgeois world literature and wants to transform this world literature, performatively, into a different world literature, a new world literature in the making. This is the project of becoming international literature as Engels records it triumphantly in his preface to the English edition of 1888: 'It [the Manifesto] is . . . the most international production of all Socialist literature' (135-136). International literature is not status but a goal, an ongoing project. With Goethe, Engels is saying that the age of international socialist literature is at hand and that we 'must strive to hasten its approach.' This new form of world literature, which remains a thing of the future, is already on its way through none other than the Manifesto itself. (Puncher, 2006, p. 58)

Although this approach allows people of different backgrounds to cohere, realize their potentials, and foster a more communally racial and international solidarity, it is rather difficult to bring into fruition its ideal ends and ideas. At first glance, it seems rather an exaggeration to claim that all the conflicts of identities could be unraveled and resolved through a constant translation of literary masterpieces to affect people to change their condition. Moreover, how could the acceptance and centralization of world literature augur well for the decline of national, particularly English and other European supremacy?

Another postcolonial theorist whose works merit scrupulous attention in this regard is Homi K. Bhabha. In his provocative series of essays, The Location of Culture (1994), Bhabha attempts to recast the notion of identity and national affiliation by constructing a controversial theory of cultural hybridity, going way beyond what others had previously gone. To this end, Bhabha develops an argument against binary division in a similar discourse. He claims that such binary divisions fail to see and shed light on the sophisticated and intertwined relationships in postcolonial discourses; in other words, it has reduced the very nature of discourse to matters of past and history and we "require a movement away from a world conceived in binary terms..." (p. 14). Whereas Bhabha, implementing the theories of Lacan, throws down the gauntlet to the essentialist and binarity thinking, stating that identity is not only binary whatsoever, but there is also a third space which is "in between the designation of identity... this interstitial passage between fixed identifications opens up the possibility of cultural hybridity that entertains the difference without an assumed or imposed hierarchy" (ibid, p. 4). He introduced the concept of "hybridity" that challenges the presupposition of the authenticity of both the colonized and colonizer of any essentialist account of identity (ibid, p. 58). World literature, as the present paper has been trying to clarify, can make a substantial and invaluable contribution to the hybridization and fraternization of different cultural identities and ultimately divest them of their deeply-ingrained racial and cultural prejudices by means of facilitating a familiarization with the colonized culture and literature; decentralization of western canon by the incorporation and replacement of parallel oriental works; and disruption of the supposed unity of western canon by introducing strange (to Western readers) concepts in their works.

In his seminal work, The Western Canon, Harold Bloom maintains an aesthetic conception of canon that may clash with some aspects of world literature. $\mathrm{He}$ believes that the canon, especially the works of Shakespeare, Dante, and Chaucer, as the most representative examples, possess traces of aesthetic originality that the Marxists, Feminists, Foucaultinspired New Historicists and Post-colonialists fail to appreciate, principally because the conceptions they have developed of literature are overly politicized and non-aesthetic (1994, p. 247). He refers to them as members of the "School of Resentment." Bloom's standard of a good canon is affected by his persistent reading of Shakespeare, to whom he ascribes the great humanistic values in the first place. However, Bloom's limited knowledge of Oriental and Eastern literary masterminds such as Saadi, Hafiz, and others makes his canon very prejudiced. Do great Persian poets of the past not represent human values? and are these humanistic values not more attainable through world literature? It seems, by and large, that Bloom's account should not begrudge the expansion of the canon; rather, it must welcome a version of world literature that maintains these human values to other parts of literature in the world as well.

Recently, many thinkers and theorists have been gravitated towards critically reflecting upon and discussing notions and theoretical frameworks associated with newly-emerged phenomena such as multiculturalism, cross-cultural immigration, worldliness, cosmopolitanism, etc.; as a result, world literature has 
hereupon grown in its popularity and significance. Accordingly, many universities today from all around the world have begun incorporating courses entitled "World Literature" or "Comparative Literature" into their educational curricula of both their undergraduate and graduate programs. World literature, as a novel and progressive approach in comparative literary studies is meant to serve permanent humanitarian and peaceful purposes, uniting all nations from around the globe in that this world literature resists exclusivity and monopolization by any hegemonic nation or socioideological faction who practice political, racial, and ethnic partisanship; it belongs to all peoples and nations, irrespective of their gender, class, ethnicity, culture, language, race, etc. (Anushiravani, 2015, p. 40). It is now a universal urgency that in order for people of the world to resolve conflicts and misunderstandings and quell violence and horror, everyone should, in a concerted effort, strive for bringing close together the spirits of the peoples, nations, and their cultures so that they could, at least partially, effectuate and ultimately practice a peaceful co-existence, away from confrontational and oppositional binaries (ibid). Literature, ultimately, can be said to be possessed of a determinative and perpetual role in initiating and conceptualizing the dialogic interactions between civilizations and promoting culturally-oriented diplomacies that do have the potential to foster the tolerance towards diversity and develop an immediate and prudent sense of political, racial, sexual and social awareness among non-demarcated nations.

\section{CONCLUSION}

The concept of world literature ultimately aims at allowing a mutual recognition and effectuating a reconciliation between diverse nations and races across concocted divides; it tries to bring people to a better understanding of each other and of their common and different features. At the end of the spectrum, there is an endeavor to keep the faith, a faith in the humanistic values in a democratic and liberal society, an attempt to get a glimpse of former colonies and colonizers, and whether the discourse of colonialism would still be inherent in their literature. However, the forces of radicalization pose a great threat to achieving universal and mutual goals between the nations in the present world. Accordingly, the task for the writers today is to break the boundaries circumscribing different literary canons and to integrate different works belonging to different nations, particularly that of the colonized and the colonizer under one unified social, political, and cultural banner, so that the binary opposition will hopefully come to an end.

\section{REFERENCES}

Amoko, A. O. (2010). Postcolonialism in the wake of the Nairobi Revolution: Ngugi wa Thiong'o and the idea of African Literature, New York: Springer.

Anushiravani, A. (2015). Amuzesh-e Adabiat-e Englisi ya Adabiat-e Jahan be Englisi dar Daneshgah-ha-ye Iran? [The pathology of teaching English literature in Iran]. Pazhuhesh-e Adabiat-e Moaser-e Jahan, 19(1), 25-43. doi: 10.22059/JOR.2014.52049.

Ashcroft, B., Helen T., and Gareth G. Eds. (1995). The Post-colonial studies reader. New York: Routledge.

Bhabha, H. K. (1994). The location of culture. London: Routledge.

Bloom, H. (1994). The Western canon. San Diego: Harcourt.

Brydon, D. (2015). Ngugi wa Thiong'o "On the Abolition of the English Department" (1972). ESC: English Studies in Canada, 41(4), 3. doi: 10.1353/esc.2015.0074.

Crocco, F. (2014). Literature and the growth of British nationalism: The influence of Romantic poetry and Bardic criticism. Jefferson: McFarland.

Cuddon, J. A. (2013). A dictionary of literary terms and literary theory. 5th Ed. Hoboken: WileyBlackwell.

Damrosch, D. (2003). What is world literature? Princeton: Princeton UP.

D'haen, T, Damrosch D, and Djelal Kadir. (2011). The Routledge companion to world literature. New York: Routledge.

Domínguez, C., Saussy H., and Villanueva D. (2015). Introducing comparative literature: New trends and applications. New York: Routledge.

Eagleton, T. (2008). Literary theory: An introduction. Hoboken: John Wiley \& Sons.

Eckermann, J. P. (2011). Conversations of Goethe with Eckermann and Sorret. John Oxenford, trans. Cambridge: Cambridge University Press.

Gandhi, L. (1998). Postcolonial theory: A critical introduction. Crows Nest: Allen \& Unwin.

Greenblatt, S. (Ed.). (2006). The Norton anthology of English literature. 8th ed. Vol. B. New York: Norton.

Hegel, G.W. F. (1998). Hegel reader. Stephen Houlgate (Ed.). London: Blackwell.

Javidshad, M. (2018). "Analysis of canonical works in two versions of the Norton Anthology of English Literature." Literary Criticism, 40(10), 167-184. Retrieved from: http://lcq.modares.ac.ir/article29-22979-fa.html.

Jost, F. (1974). Introduction to comparative literature. New York: Pegasus. 
Kruger, M. J. (2012). Canon revisited: Establishing the origins and authority of the New Testament Books. Wheaton: Crossway.

Macaulay, T. B. (1965). "Selections from Educational Records."

Moretti, F. (2000). "Conjectures on World Literature." New Left Review, 1, 54-68.

Puncher, M. (2006). The poetry of the revolution: Marx, manifestoes and the Avant-gardes. Princeton: Princeton University Press.

Robertson, R. (2016). Goethe: A very short introduction. Oxford: Oxford University Press.

Roebuck, J. A. (1849). The colonies of England. New York: New York Public Library.

${ }^{\mathrm{i}}$ For more readings and insights on "Internal Colonialism" check out Internal Colonialism: The Celtic Fringe in British National Development, a well-researched and widely-acclaimed book by Michael Hechter, originally published in 1972.
Said, E. W. (1978). Orientalism. New York: Pantheon Books.

---. (1983). The world, the text, and the critic. Cambridge: Harvard University Press.

Sinfield, A. (1992). Faultlines: Cultural Materialism and the Politics of Dissident Reading. Oxford: Clarendon Press.

Trivedi, P. (2017). Shakespeare and Asian classics. In S. Keilen \& N. Moschovakis (Eds.), The Routledge research companion to Shakespeare and Classical Literature. London: Routledge.

Vafa, A. (2016). Recasting American and Persian literatures: Local histories and formative geographies from Moby-Dick to Missing Solouch. London: Palgrave Macmillan.

ii Masterpieces

iii http://www.clai.in/index.html 